\title{
Clinicopathological Study of Renal Cell Carcinoma - A Study of 100 Cases
}

\author{
Md. Mohiur Rahman Khan', Muhammad Rafiqul Hassan², Fahmin Rahman ${ }^{3}$, ATM Mowladad Chowdhury ${ }^{4}$
}

\begin{abstract}
Background \& objective: Renal Cell carcinoma (RCC) accounts for 2 - 3\% of all malignant adult neoplasm and is associated with a mortality of $30-40 \%$. It is not well responding to the conventional chemo and radiotherapy and in early stages of the disease, radical nephrectomy is the treatment of choice. A detailed clinoco-pathological study is of paramount importance to understand its management. The aim of this study is to describe the clinical characteristics and histopathological spectrum of RCC.
\end{abstract}

Methods: This Cross-sectional descriptive study was carried out in the Department of Urology, BIRDEM General Hospital and Dhaka Medical College Hospital over a period 10 months from June 2013 to March 2014. All FNA positive renal cell carcinomas were included in the study. A total of 100 cases of RCC irrespective of age and sex were selected and their anatomical distribution, clinical presentation, stage at presentation and histopathological type were studied.

Result: The peak incidence of renal cell carcinoma was observed to be between $4^{\text {th }}$ and $5^{\text {th }}$ decades of life. The median age was 52.3 years. A male predominance was observed in the series with male-to-female ration being 3:1. Two-thirds $(67 \%)$ of the patients were diagnosed incidentally, $23 \%$ presented with pain and heamaturia and $10 \%$ with loin mass. A sizable proportion of the patients was found to have paraneoplastic syndrome [raised ESR $(60 \%)$, hypertension $(50 \%)$, anaemia(40\%), weight loss (15\%), pyrexia (2\%)and hypercalcamia (2\%)]. Tumours mainly involved the right kidney in its upper pole (55\%). In 60\% cases the size of the tumour extends between 3-7 cm. Most of the tumours were diagnosed at Robsing stage II (66\%). Histopathological diagnosis showed that $70 \%$ had clear cell sub-type RCC, $20 \%$ papillary sub-type, $5 \%$ chromophobe and $5 \%$ othersub-types.

Conclusion: Renal cell carcinoma generally occurs in older persons with a male preponderance, It occurs mainly in right kidney preferably in the upper pole. Patients usually present with paraneoplastic syndrome (raised ESR, hypertension, anaemia, weight loss etc.). The typical triad of pain, flank mass and microscopic hematuria is rare. Two-thirds of the RCC are diagnosed incidentally at Rosing stage-II and majority is of clear-cell sub type.

Key words: Renal cell carcinoma, clinical and pathological characteristics etc.

\section{INTRODUCTION:}

Renal cell carcinoma is a group of malignancies arising from the epithelium of the renal tubules. ${ }^{1}$ Overall, approximately 12 new cases are diagnosed per 100,000 populations per year, with a male-to-female ratio of $3: 2$. Worldwide, the mortality from renal cell carcinoma is estimated to exceed 100,000 per year. Renal cell carcinoma occurs predominantly in the sixth to eighth decades of life. $^{2}$ It is uncommon in patients younger than 40 years and rare in children. ${ }^{3}$ Most sporadic RCCs are unilateral and unifocal. Bilateral involvement is found in 2 to $4 \%$ of cases.

\section{Authors' information:}

Dr. Md. Mohiur Rahman Khan, Registrar, Department of urology, BIRDEM (Bangladesh Institute of Research and Rehabilitation in Diabetes, Endocrine and Metabolic Disorders) General Hospital, 122 Kazi Nazrul Islam Avenue, Dhaka-1000, Bangladesh

${ }^{2}$ Dr. Muhammad Rafiqul Hassan, Assistant registrar, department of urology, BIRDEM (Bangladesh Institute of Research and Rehabilitation in Diabetes, Endocrine and Metabolic Disorders) General Hospital, 122 Kazi Nazrul Islam Avenue, Dhaka-1000, Bangladesh

${ }^{3}$ Dr. Fahmin Rahman, MBBS, MPH, Department of Public Health, North South University (NSU), Bashundhara, Dhaka-1229, Bangladesh.

${ }^{4}$ Prof. ATM Mowladad Chowdhury, FCPS (Surgery), MRCSED, MRCPS, MS (Urology), Department of Urology, BIRDEM General Hospital \& Ibrahim Medical College, Dhaka.

Correspondence: Dr. Md. Mohiur Rahman Khan, Phone: +880 1727346249 E-mail: babumohiur@yahoo.com 
Multicentricity, found in $10-20 \%$ of cases, is more common in association with papillary histology and familial RCC. One unique feature of RCC is its predilection for involvement of the venous system (in $10 \%$ of RCCs), more often than in any other tumor type. The tumor can extend directly into the perinephric fat, ipsilateral adrenal gland, or adjacent musculature, and, less frequently to the liver, spleen, pancreas, and colon. Rarely, the tumor may invade the renal collecting system. RCC has a propensity for extending, as tumor thrombus, into the tributaries of the renal veins and subsequently to the main renal vein, the inferior vana cava, the hepatic veins, and potentially to the right atrium. Hematogenous metastases are more common and occur earlier than lymphatic dissemination, the former most commonly to the lungs and bone, but essentially to any organ, including the subcutaneous tissues and skeletal muscle. Nuclear features can be highly variable. Grading is primarily based on nuclear size and shape and the presence or absence of prominent nucleoli. Fuhrman's system has been most generally adopted and is now recognized as an independent prognostic factor for RCC in general and for clear cell RCC in particular. ${ }^{4}$

The classic clinical presentation of flank pain, hematuria, and a palpable flank mass is comparatively uncommon (5-10\% of cases). The clinical symptomatology may be quite nonspecific for example, anorexia, tiredness, weight loss, or fever of unknown origin. ${ }^{5-9}$ RCC is also more common in long-term dialysis carrying a three-to six-fold increased risk compared with the non-dialysis population. Incidentally detected tumors in asymptomatic individuals have been steadily increasing with the dissemination of imaging techniques, including CT, MRI, and sonography, accounting for approximately $60 \%$ of renal tumors in the 1990s, compared with approximately $10 \%$ in the early 1970 s. $^{10-11}$

Among all the incidentally diagnosed tumours, RCC is a tumour that progresses aggressively and becomes life-threatening in the terminal stage. Prognosis is influenced by the extent of disease at diagnosis, with a 5-year survival rate in the absence of metastases exceeding $50 \%$; in the presence of distant metastases, the 5-year survival rate decreases to $10 \%$ and a 10 -year survival rate of $<5 \%$. The tumour is not wellresponding to the conventional chemo and radiotherapy and still radical nephrectomy is the treatment of choice which in many cases is curative. With the advent of modern facilities and diagnostic aids, more and more cases are being diagnosed now a day. So, a clinicopathological study of RCC is imperative which might update the medical community about different clinicopathological aspects of the tumoursessential for the early diagnosis of RCC. The present study was, therefore, intended to find the usual mode of presentation of RCC with peak age incidence, gender affinity and laterality. The study was also intended to find histologic details of the tumours.

\section{METHODS:}

This Cross-sectional descriptive study was carried out in the Department of Urology, BIRDEM General Hospital and Dhaka Medical College Hospital over a period 10 months from June 2013 to March 2014. All FNA positive renal cell carcinomas were included in the study. Renal tumours other than renal cell carcinoma diagnosed by FNA, such as, angiolipoma, renal cyst, and renal tuberculosis were excluded. A total of 100 renal cell carcinoma patients, irrespective of age and sex, were selected and their anatomical distribution, clinical presentation, stage at presentation and histopathological type were studied. Having obtained ethical clearance from the Ethical Committee and verbal consent from the patients, the data collection was commenced. Data processing and analysis were done using SPSS (statistical package for social sciences), version 17 . The test statistics used to analyze the data were descriptive statistics.

\section{RESULTS:}

Demographic characteristics of the patients show that $70 \%$ patients were between $46-55$ years old, $14 \%$ between $56-65$ years, $8 \%$ between $66-75$ 
years, $6 \%$ between $35-45$ years, and $2 \%$ above 75 years old. The median age at diagnosis was 52.3 years and the youngest and the oldest patients were 35 and 78 years old respectively. Three-quarters (75\%) of the cases of renal cell carcinoma were male and the rest $25 \%$ were female (male to female ratio is $3: 1$ ) (Table I). Over half $(53 \%)$ of the cases of RCC had their lesion in right kidney and $47 \%$ in the left kidney. In $55 \%$ cases the lesion occurred in upper pole and in $45 \%$ cases in lower pole. Two-thirds (67\%) of the patients were diagnosed incidentally, 23\% presented with pain and heamaturia and $10 \%$ with loin mass (Table II). On physical examination and laboratory investigation, a sizable proportion of the patients was found to have paraneoplastic syndrome [raised ESR (60\%), hypertension (50\%), anaemia $(40 \%)$, weight loss $(15 \%)$, pyrexia $(2 \%)$ and hypercalcamia (2\%)] (Table III). CT scan of the tumour revealed that, $60 \%$ were between 3-7 $\mathrm{cm}, 30 \%$ were more than $>7$ and $10 \%<3 \mathrm{~cm}$. Two-thirds (66\%) of RCC cases were diagnosed at Robsing Stage II, 20\% at stage III (of them $8 \%$ had renal vein or inferior venacaval involvement and $12 \%$ had nodal involvement) \& $12 \%$ at stage I and $2 \%$ at stage IV disease. Staging was done pre-operatively by CT scan according to Robsing staging system (Table IV). Histopathological diagnosis showed that $70 \%$ had clear cell sub-type RCC, $20 \%$ papillary sub-type, 5\% chromophobe and $5 \%$ were of other subtypes (such as collecting duct, medullary carcinoma, renal cell carcinoma and unclassified) (Figure 1).

\begin{tabular}{|c|c|c|}
\hline Demographic characteristics & Frequency & Percentage \\
\hline \multicolumn{3}{|l|}{ Age (years) } \\
\hline $35-45$ & 6 & 6.0 \\
\hline $46-55$ & 70 & 70.0 \\
\hline $56-65$ & 14 & 14.0 \\
\hline $66-75$ & 8 & 8.0 \\
\hline$>75$ & 2 & 2.0 \\
\hline \multicolumn{3}{|l|}{ Sex } \\
\hline Male & 75 & 75.0 \\
\hline Female & 25 & 25.0 \\
\hline
\end{tabular}

Table II: Distribution of patients by site of lesion \& clinical presentation $(n=100)$

\begin{tabular}{llc}
$\begin{array}{l}\text { Site of lesion \& clinical } \\
\text { presentation }\end{array}$ & Frequency & Percentage \\
\hline $\begin{array}{l}\text { Site of lesion } \\
\text { Right kidney }\end{array}$ & 53 & 53.0 \\
Left kidney & 47 & 47.0 \\
Upper polar & 55 & 55.0 \\
Lower polar & 45 & 45.0 \\
Clinical presentation & & \\
Abdominal pain and heamaturia & 23 & 23.0 \\
Lion Mass & 10 & 10.0 \\
Incidental diagnosis & 67 & 67.0
\end{tabular}

Table III: Distribution of patients by paraneoplastic syndrome $(n=100)$

$\begin{array}{lcc}\text { Paraneoplastic syndrome } & \text { Frequency } & \text { Percentage } \\ \text { ESR } & 60 & 60.0 \\ \text { Hypertension } & 50 & 50.0 \\ \text { Anaemia } & 40 & 40.0 \\ \text { Weight loss } & 13 & 13.0 \\ \text { Pyrexia } & 02 & 02.0 \\ \text { Hypercalcernia } & 02 & 02.0\end{array}$

Table IV: Distribution of the patients by the size and stage of the tumours $(n=100)$

\begin{tabular}{|c|c|c|}
\hline Size and stage of the tumours & Frequency & Percentage \\
\hline \multicolumn{3}{|l|}{ Sizeof the tumour $(\mathrm{cm})$} \\
\hline$<3$ & 10 & 10.0 \\
\hline $3-7$ & 6 & 60.0 \\
\hline$>7$ & 30 & 30.0 \\
\hline \multicolumn{3}{|l|}{ Stage of disease (Robsing staging) } \\
\hline $\begin{array}{l}\text { Stage I (tumour confined within } \\
\text { the renal capsule) }\end{array}$ & 12 & 12.0 \\
\hline $\begin{array}{l}\text { Stage II (tumour invasion to the } \\
\text { perinephric fat but confined } \\
\text { to the fascia Gerota) }\end{array}$ & 66 & 66.0 \\
\hline $\begin{array}{l}\text { Stage III (renal vein/inferiorvenacav } \\
\text { involvement +nodal involvement) }\end{array}$ & 20 & 20.0 \\
\hline $\begin{array}{l}\text { Stage IV (extra renal metastasis- } \\
\text { adrenal, splenic, liver, bone, lungs }\end{array}$ & 2 & 2.0 \\
\hline
\end{tabular}




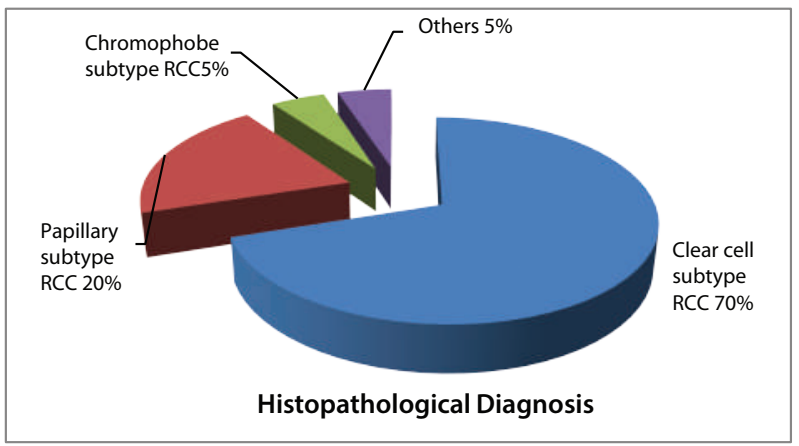

Fig.1 Distribution of patients by their histopathological diagnosis

\section{DISCUSSION:}

All the 100 cases of renal carcinoma provisionally diagnosed clinically and CT scan were finally confirmed by histo-pathological examination. In our study, $70 \%$ of patients presented between 46-55 years of age with median age at diagnosis being 52.3 years indicating that the peak ageincidence of the RCC in our country is between $4^{\text {th }}$ and $5^{\text {th }}$ decades of life. Studies conducted in Czech Republic $^{12}$ Brazil $^{13}$ and Columbia University ${ }^{14}$ demonstrated higher median age at diagnosis (62, $60 \& 61$ years respectively). Chow and Deves ${ }^{5}$ and Zubacet al ${ }^{15}$ showed most RCC to present in the fifth to seventh decade of life with median age at diagnosis being 66 years. As the present study was conducted in the two hospitals of Dhaka city, the findings do not represent the true picture of a cross-section of population and as such they lack generalization. In terms of sex distribution, $75 \%$ was male with male to female ratio being $3: 1$. In a review study in Columbia University, Medical Centre, New York Database, out of 1105 patients of RCC, two-thirds (66.1\%) were male and one-third (33.8\%) was female and in another study conducted in Brazil, out of 508 patients of RCC, nearly $60 \%$ were male with male to female ratio being $6: 4 .{ }^{13}$ In a study in Kathmandu, out of 50 patients with RCC, $64 \%$ were male and $36 \%$ were female. ${ }^{16}$ Zubac et $a^{15}$ also showed a male-female ratio of $2: 1$. Thus, it is evident from the above-mentioned studies, that RCC cases are predominantly male which is consistent with the findings of the present study.

In our study, we found that $53 \%$ cases of RCC had their lesion in right kidney and 55\% were located in the upper pole. In a study, Tribhuvan University Teaching Hospital, Kathmandu showed RCC to occupy upper pole of the kidney in $40 \%$ of cases. ${ }^{16}$ In a retrospective review analysis in the University College Hospital, Ibadan showed that the right kidney was more commonly affected (58.6\%). ${ }^{17}$ The reason why RCC occurs in right kidney preferably in upper pole is still not known. Plebani ${ }^{18}$ showed that ESR plays a major part in paraneoplastic syndrome in RCC and in another study ${ }^{19}$, ESR was identified as a significant independent prognostic factor in patients with localized RCC. In Campbell-Walsh Urology (edition, 10) the author says that in RCC, paraneoplastic syndromes are found in $20 \%$ of patients. Among these raised ESR was found in $55.6 \%$, hypertension in $37.5 \%$, anaemia in $36.3 \%$, weight loss in $34.5 \%$, pyrexia in $17.2 \%$, abnormal Liver Function Tests (LFT) in $14.4 \%$, hypercalcemia in $4.9 \%$, polycythemia in $3.5 \%$. neuromyopathy in $3.4 \%$ \& amyloidosis in $2.0 \%$ casas. ${ }^{1}$ In the above study, abnormal liver function test, polycythemia, amyloidosis are included as paraneoplastic syndrome. But in our study we are unable to show these as paraneoplastic syndrome. The reason is that these investigations are not frequently done in our country, so we did not have enough data to present these signs and symptoms in our study. About $60 \%$ of RCCs were between $3-7 \mathrm{~cm}, 30 \%$ were more than $7 \mathrm{~cm}$ and $10 \%$ were less than $3 \mathrm{~cm}$. In a study conducted by Crispenet $\mathrm{al}^{20}$ showed that tumour size more than $10 \mathrm{~cm}$ had chance of lymph node metastasis in $38 \%$ cases. In a Japanese study, Okudaet al ${ }^{21}$ showed that if RCC tumour size is less than $5 \mathrm{~cm}$, nephron sparing surgery can be done which is further supported by Ljungberget al. ${ }^{22}$ These studies also reported that tumour size $<5 \mathrm{~cm}$ has less chance of metastasis and in these cases nephron sparing surgery is possible. In our study most of the tumours was of size $3-7 \mathrm{~cm}$.

In our study we found that $67 \%$ patients were diagnosed as RCC incidentally, 23\% presented with pain and hematuria and $10 \%$ presented with loin mass. Tatsuya et $\mathrm{al}^{23}$ from Japan and Bazaev ${ }^{24}$ et al from Russia reported that more than $65 \%$ of the patients were diagnosed incidentally. In 
another study, out of 50 patients with RCC, the typical triad of pain, flank mass and microscopic hematuria was present in only $4 \%$ cases. $^{16}$ Choykeet $\mathrm{al}^{27}$ showed that the classic clinical presentation of flank pain, hematuria, and a palpable flank mass is comparatively uncommon (5-10\% of cases). However, clinical symptomatology may be quite nonspecific for example, anorexia, tiredness, weight loss, or fever of unknown origin or varicocele formation (from tumor thrombus in the left renal vein or the inferior vena cava) and disseminated malignancy.

Histological examination showed that nearly two-thirds $(66 \%)$ of the patients were diagnosed in Robsing Stage II and $20 \%$ in stage-I. Poprach et $\mathrm{al}^{12}$ demonstrated that out of 544 patients of RCC, $46.5 \%$ were diagnosed as stage I, $10.7 \%$ as stage II, $13.1 \%$ as stage III and $20 \%$ as stage IV, while Bazaev et al ${ }^{24}$ showed most of the RCCs are diagnosed in stage I and stage II. Igarashi and colleagues $^{25}$ found that $4 \%$ patients had apparent tumour thrombi in the main renal vein and $6 \%$ had distant metastasis at the time of operation. O'Malley et $a^{26}$ showed that only $2 \%$ cases of RCC had adrenal gland metastasis. In our study out of 100 patients 8 had renal vein or IVC extension and only 2 cases had distant metastasis to adrenal gland. In the present study, $70 \%$ of the cases were diagnosed as clear cell sub-type RCC and $20 \%$ as papillary sub-type. Several studies reported that clear-cell sub-type RCC formed the majority (around 80\%) $2,12,16$ Kovacs \& associates ${ }^{27}$ showed clear cell adenocarcinoma to form the majority $(80 \%)$ followed by papillary $(15 \%)$, chromophobe $(5 \%)$, collecting duct $(1 \%)$ and unclassified $(4 \%)$ sub-type.

\section{CONCLUSION:}

Renal cell carcinoma is a highly aggressive tumour and generally occurs in older persons (between $4^{\text {th }}$ and $5^{\text {th }}$ decades of life) with a male predilection. It occurs mainly in right kidney preferably in the upper pole. Patients usually present with paraneoplastic syndrome (raised ESR, hypertension, anaemia, weight loss etc.). The typical triad of pain, flank mass and microscopic hematuria is rare. Two-thirds of the RCCs are diagnosed incidentally at Rosing stage-II. Histologically majority is of clear-cell sub type. If detected early, young patients with Robsing stage I may have better overall 5 years survival rates.

\section{REFERENCES:}

1 World Health Organization Classification of Tumours International Agency for Research on Cancer (IARC) Pathology and Genetics of Tumours of the Urinary System and Male Genital Organs Edited byJohn N. Eble Guido Sauter, Jonathan I. Epstein Isabell A. Sesterhenn, IARC Press Lyon, 2004 Eble A Sauter G, Epstein JI, Sesterhenn IA, editors: World Health Organization Classification of Tumours. In Pathology And Genetics Of Tumours Of The Urinary System And Male Genital Organs. Lyon: IARC Press; 2004: 9-84.

2 Landis SH, Murray T, Bolden S, Wingo PA. Cancer statistics. CA Cancer J Clin 1999;49(1):8-31.

3 Pantuck AJ, Zisman A, Belldegrun AS. The changing natural history of renal cell carcinoma. J Urol 2001; 166:1611-23.

4 Fuhrman SA, Lasky LC, Limas C. Prognostic significance of morphologic parameters in renal cell carcinoma. Is J Surg Path 1982;6(7):655-63.

5 Chow WH, Devesa SS, Warren JL, Fraumeni JF Jr. Rising incidence; renal cell cancer in the United States. JAMA $1999 ; 281: 1628-31$.

6 Russo P. Renal cell carcinoma: presentation, staging, \& surgical treatment. Semin Oncol 2000;27(2):160-76.

7 Figlin RA. Renal cell carcinoma: management of advanced disease. J Urol 1999;161:381-387.

8 Pretorius ES, Wickstrom ML, Siegelman ES. MR imaging of renal neoplasms. Magn Reson Imaging Clin N Am 2000;8:813-36.

9 Godley P, Kim SW. Renal cell carcinoma. Curr Opin Oncol 2002; 14:280-85.

10 Luciani LG. Cestari R, Tallarigo C. Incidental renal cell carcinoma: age and stage characterization and clinical implications-study of 1092 patients (1982-1997). Urology 2000;56:58-62.

11 Jayson $M$, Sanders $H$. Increased incidence of serendipitously discovered renal cell carcinoma. Urology 1998;51:203-05.

12 Poprach A, Lakomy R, Selingerova I, Doleckova B, NilekO, Hezova $R$ et al. Epidemiological and clinicopathologicalcharacteristics of patient with renal cell carcinoma : a single institution analysis of 544 cases. Klin Onkol 2013;16(2):114-23. 
13 Nardi AC, Zequi S, Clark AC, Almeida JC, Sidney G. Epidemiologic characteristics of renal cell carcinoma in brazil. Int. Braz J Urol 2010;36(2):151-158.

14 Pierorazio PM, Murphy AM, Benson MC, McKiernan JM. Gender discrepancies in the diagnosis of renal cortical tumours. World J Urol 2007;25(1):81-5.

15 Zubac DP, Bostad L, Gestblom C, Kihl B, Seidal T, Wentzel-Larsen T, Bakke AM. Renal cell carcinoma: a clinicopathological follow-up study after radical nephrectomy. Scand J Urol Nephrol 2007;41(3):191-7.

16 Sidharth. Luitel BR, Gupta DK, Maskey P, Chalise PR, Sharma UK et al. Pattern of Renal Cell Carcinoma - A Single center Experience in Nepal. Kathmandu Univ Med J 2011;9(35):18.

17 Odubanjo MO Akang EE. Histopathological pattern of renal cell carcinoma in Ibadan. Afr J Med Sci 2010; 39(4):317-21.

18 Plebani M, Piva E. Erythrocyte sedimentation rate: use of fresh blood for quality control. Am J Clin Pathol 2002;117(4):621-6.

19 Sengupta S, Lohse CM, Cheville JC, Leibovich BC, Thompson RH, Webster VVS, et al. The preoperative erythrocyte sedimentation rate is an independent prognostic factor in renal cell carcinoma. Cancer 2006; 106(2):304-12.

20 Crispen PL, Breau RH, Allmer C, Lohse CM, Cheville JC, Leibovich BC et al. Lymph node dissection at the time of radical nephrectomy for high-risk clear cell renal cell carcinoma: indications and recommendations for surgical templates. Eur Urol 2011;59(1):18-23.

21 Okuda H, Horita S, Ito F, Ryoji 0, Onitsuka S, Kihara K et al. Sex and the clinical value of body mass index in patients with clear cell renal cell carcinoma. Japan association of urology 2014:19-3.

22 Lungberg B. Nephron-sparing surgery-straegies for partial nephrectomy in renal call carcinoma. Cancer 2002;106(2):304-12.

23 Nakatani T, Yoshida N, Iwata H, Kuratsukuri K, Uchida J, Kawashima $\mathrm{H}$, Ikemoto $\mathrm{S}$, Sugimura $\mathrm{K}$. A clinicopathological study of renal cell carcinoma. Afr J Med Sci 2010;39(4):317-21.

244 Bazaev VV, Dutov VV, Tian PA, Kazantseva IA. Incidental renal cell carcinoma: clinical and morphological features. Urologiia 2013;(2):66-8.

25 Igarashi T, Murakami S, Hara S, Tanaka S, Oki T, Isaka $S$ et al. Clinicopathological study of renal cell carcinoma. J Clin Pathol 2002;127(4):621-6.

26 O'Malley RL, Godoy G, Kandofsky JA, Taneja SS. The necessity of adienalectomy at the time of radical nephrectomy: a systematic review. J U pathol 2002; 177-4.

27 Kovacs G, Akhtar M, Beckwith BJ, Bugert P, Cooper CS, Delahunt $B$ et al. The Heidelberg classification of renal cell tumours. J Pathol 1997;183(2):131-3. 